\title{
VRCHOLNĚ STŘEDOVĚKÝ NÁNOSNÍK Z MOBILIÁRNÍHO FONDU STÁTNÍHO ZÁMKU KOZEL JAKO PŘÍKLAD PRVNÍCH ARCHEOLOGICKÝCH VÝZKUMŮ A MOŽNOSTI JEHO INTERPRETACE
}

\author{
PAVEL MACKU゚ - VERONIKA PILNÁ
}

\begin{abstract}
Abstrakt: V mobiliárním fondu zámku Kozel se nacházi kovový nánosník vyspělé konstrukce, jenž byl s oblibou upevňován na přilby předevšim v pokročilém 14. století. Jedná se o starý nález bez adekvátní dokumentace a neznáme ani nálezové okolnosti ani misto nálezu. Jde ovšem o exemplár morfologicky i rozměrově téměr totožný s nedávno publikovaným nánosnikem z hradu Ronovce (Knápek-Macků 2016), přičemž kozelský nánosník je dochovaný v mnohem lepšim stavu a je stále pohyblivý. Cílem tohoto přispěvku není znovu popisovat vývoj tohoto druhu militaria ve středověku, ale doplnit doposud neúplnou mozaiku o možnostech ,sériové“ výroby specifických předmètù-militarií ve 14. století.
\end{abstract}

Klíčová slova: militarium - nánosník-zámek Kozel - hrad Ronovec.

A nosepiece from the high Middle Ages in the collections of Kozel Chateau as an example of the beginnings of archaeological research, and the possibilities of its interpretation

\begin{abstract}
The Kozel Chateau collections contain a metal nosepiece of advanced construction which was once a popular feature attached to helmets, especially in the late 14th century. It is an old find without adequate documentation, and neither the context nor the site where it was found are known. The specimen is in its morphology and size almost identical to a recently published nosepiece from Ronovec Castle (Knápek-Macki 2016), yet the Kozel one has survived in a much better condition and is still mobile. The main objective of this article is not to describe again the development of this kind of militaria in the Middle Ages but to fill in gaps in an incomplete mosaic regarding the possibilities of the "serial" production of specific items - militaria, in the 14th century.
\end{abstract}

Key words: militarium - nosepiece - Kozel Chateau - Ronovec Castle.

Během 19. století se společně se zájmem o vědu rozšířila také záliba některých vzdělaných příslušníků šlechty o historické průzkumy památek v okolí jejich sídel. S průzkumy se dostaly do zámeckých knihoven a kabinetů kuriozit různé předměty pocházející z takových amatérských průzkumů. V mobiliárním fondu zámku Kozel (okr. Plzeň-město) díky této pozornosti k tzv. „starožitnostem“ uchováváme menší soubor historických archeologických nálezů pocházející z dvou období prvotních archeologických vykopávek na Štáhlavsku. Výraznou památkou mezi těmito předměty je unikátně dochovaný nánosník evidovaný pod číslem KZ3481 (obr. 1 vlevo).

\section{Zámek Kozel, jeho mobiliární fond a archeologické výzkumy Št’áhlavska}

Zámek Kozel byl ve štáhlavském panství postaven na jižním svahu návrší Boru nad údolím řeky Úslavy jako lovecký zámeček hraběte Jana Vojtěcha Černína z Chudenic (1746-1816). V roce 1816 získal zámek po svém strýci hrabě Kristián Vincent z Valdštejna-Vartenberga (1794-1858). V majetku rodiny Valdštejnů zůstal až do roku 1945. Mobiliární fond v současnosti obsahuje celkem 4905 inventárních čísel a je složen z řady druhových skupin mobiliáře včetně archeologických nálezů. ${ }^{1}$ Dnes se zde nacházejí archeologické nálezy pravděpodobně po dvou obdobích amatérských výzkumů. V této oblasti je známé především působení amatérského archeologa Františka Xavera France (1838-1910), který na zámku pracoval současně jako zahradník.

František Xaver Franc během svého působení na Štáhlavsku a Plzeňsku zkoumal velké množství lokalit. Mezi lety 1878 až 1906 provedl řadu výzkumů a zpracoval nálezové zprávy k lokalitám Bzí, Sváreč, Lopata, Št’áhlavice, Štáhlavy a mnoho dalších (Franc 1988, 262). Ke

1 Podle evidenčního programu CastIS 2011 k 28. 8. 2019. Kompletně se jedná o 8958 inventárních jednotek mobiliárního fondu. 


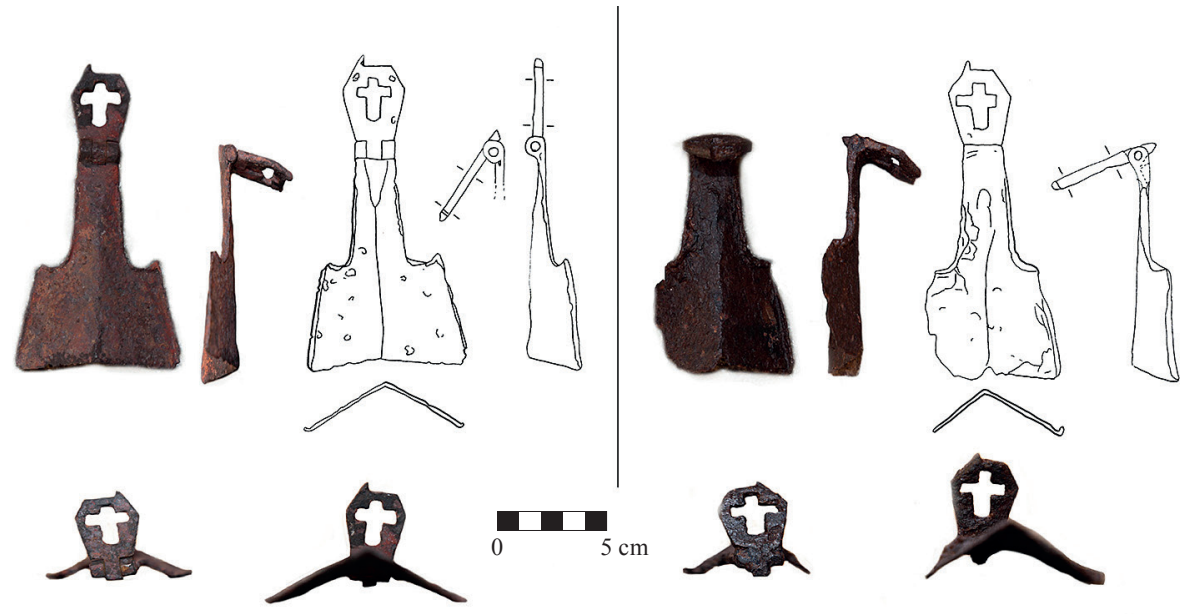

Obr. 1. Plechové nánosníky ze sbírek zámku Kozel (vlevo) a Ronovce (vpravo). Foto a kresba P. Macků.

Abb. 1. Nasale aus Blech aus den Sammlungen von Schloss Kozel (links) und von Burg Ronovec (rechts). Foto und Zeichnung P. Macků.

každému ze svých průzkumů zapsal stručný popis situace a sumář nalezených předmětů. Způsoby Francovy dokumentace byly na svou dobu ojedinělé svým rozsahem a hloubkou zaznamenávaných informací. Francova pozornost se soustředila především na mohyly, proto se nejčastěji v zápisech objevují předměty jako bronzové předměty, přesleny, zvířecí kosti, keramické fragmenty nádob a podobně. Na základě časového určení kovového nánosníku jsme předpokládali, že by mohl pocházet z výzkumů hradu Lopata, který leží nedaleko zámku Kozel. František Xaver Franc prováděl na hradě Lopata výzkumy v letech 1880 až 1886 a v letech 1883 až 1890 je zpracovával (Franc 1988, 165, 262). Sám o průzkumech zapsal: „Při všem respektu ku psané historii raději bych býval nalezl skálu tu tak neporušenou jako Velikou skálu nad Bzí. Nám bylo totiž prvé všechen rum ze zbořeného hradu odstraniti, ně̌-li jsme mohli k naši kulturní vrstvě A se dostati. Přitom však bylo nám mnohé, i co se středověku a hradu samého týče, objeviti. Byly to totiž jen paběrky, jelikož hlavněv hořejším hradě bylo vše dávno již přehrabáno a později též, jak mně bylo sděleno, za Kristiána hraběte z Valdštejna-Vartenberka, jenž r. 1816 po Černínovi z Chudenic panstvi štáhlavské byl zdèdil. V lesním zámku na Kozlu nalézá se aspoň z té doby slušná sbirka hrotů železných střel, pěkných dlaždic, částí zbroje apod. nálezư“ (Franc 1988, 188). V dalších poznámkách pak nalezneme zmínku, že předchozí výzkumy probíhaly na Lopatě o 45 let dříve, tj. přibližně kolem roku 1835 (Franc 1988, 165).

Francem zmiňovaný Kristián Vincent z Valdštejna-Vartenberga (1793-1858) náležel k významným představitelům mnichovohradišt'ské větvě rodu Valdštejnů. Během svého života zastával významné funkce komořího a tajného rady a mezi lety 1852-1858 působil jako prezident Muzea Království Českého, dnešního Národního muzea (Franc 1988, 278; Bečková 2008, 45-46; Štumbauer 2014, 478). Podrobnější informace k Valdštejnově zálibě ve starožitnostech se s největši pravděpodobností nedochovaly. Jeho zájem o archeologii tak dokládá jeho činnost v rámci společnosti českého královského muzea a archeologického sboru. Valdštejn se stal v červenci 1850 nejdříve členem této společnosti společně s několika dalšími majiteli panství v západních Čechách. O rok později v roce 1851 je podepsán jako jeden z účastníků schůzek archeologického muzejního sboru, kde nadále pravidelně zasedal (ANM 1; jeho účast prokázána napřr. na schůzkách ve dnech 25. ř́jna 1851, 29. listopadu. 1851, 27. ledna 1854, 28. února 1854; dalšími 
účastníky zasedání v roce $1850 \mathrm{~s}$ vazbami na západní Čechy byli mj. Alfred Windisgrätz a Klemens Metternich). Dva roky od zahájení své aktivní činnosti v muzejním spolku vstoupil do „„̌inných oudư“, jak je zapsáno ve vystoupení Erazíma Vocela z 29. července 1852 (ANM 2). Valdštejnové-Wartenbergové podporovali činnost královského muzea však již dřive. Z roku 1822 je doložen dar herbáře uherských rostlin od ,hrabat Valdštejnů-Vartenbergü“ (ANM 3). V rodovém archivu Valdštejnů uloženém v SOA Praha se nachází jen jeden kus korespondence odkazující na Valdštejnův vztah k archeologii, a to dopis z roku 1852 od Erazíma Vocela. ${ }^{2}$

Také se nepodařilo dohledat ani v rodových archivech Valdštejnů-Vartenbergů ani v archivu velkostatku Štáhlavy podrobnější zprávu či popis původní kozelské sbírky „starožitností“. Můžeme tedy porovnat jen typy archeologických nálezů, které zmiňuje Franc, s předměty uloženými dnes na zámku Kozel. Hroty střel se $\mathrm{v}$ mobiliárním fondu

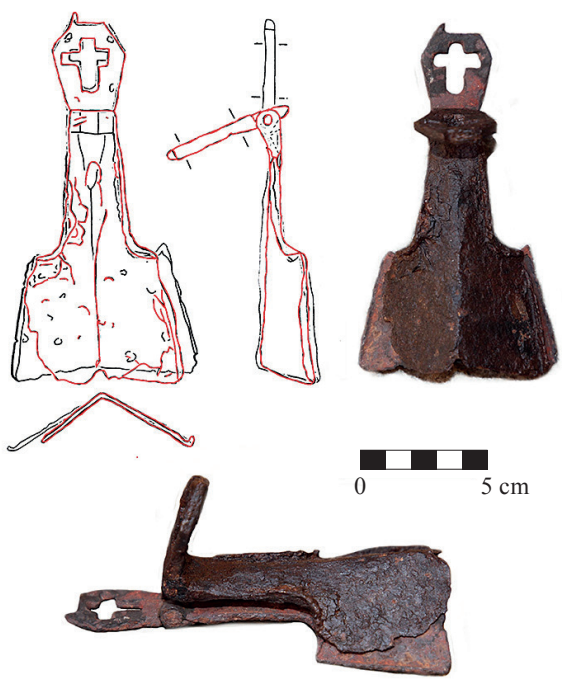

Obr. 2. Porovnání nánosníků - černou linkou kozelský a červenou ronovecký exemplář. Foto a kresba P. Macků.

Abb. 2. Vergleich zwischen den Nasalen - mit schwarzen Linien das Exemplar von Kozel und mit roten das von Ronovec. Foto und Zeichnung P. Macků. nezachovaly, ale zlomky keramických kachlů, nádob a kovové předměty jako např́iklad zde popisovaný nánosník ano. ${ }^{3}$

Artefakt je takřka totožný s nedávno publikovaným nánosníkem z hradu Ronovce (KnápekMacků 2016). Vzhledem k tomu, že jde o předmět stejné morfologie, rozměrů a v lepším stavu dochování, upřesňuje kozelský nánosník některé dříve nastíněné závěry (obr. 1-2).

\section{Popis nánosníku ${ }^{4}$}

Železný nánosník uložený v depozitáři zámku Kozel je přibližně lopatovitého tvaru a je kompletně dochován bez výrazněji chybějících částí. Odspodu vzhůru se zužuje, přičemž je zhruba ve třetině oboustranně segmentovitě vykrojen. Je složen ze tří částí a většinu hmoty tvoří spodní lopatkovitý díl, ukončený v horní části dvojicí stočených tyčinek tvořících základnu otočného pantu. Rozměrově dosahuje v nejširším místě při základně $7,15 \mathrm{~cm}$ (u ronoveckého exempláře nelze vzhledem k dochování změřit), na výšku 13,85 (ca 13,9) cm a jeho „hloubka“ díky prohnuté středové části činí 2,2 (2) cm. Konvexní vyhnutí se nachází téměř po celé délce a anatomicky tak kopírovalo nos vojáka, když byl nánosník zavěšen na přilbě a sklopen dolů. Vyhnutí zároveň zvyšovalo pevnost materiálu. I z toho důvodu jsou směrem ven (od obličeje) po celé délce vyhnuté i boční okraje. Síla materiálu je proměnlivá a zvyšuje se od základny nahoru k pantu. Spodní okraj vykazuje tloušt'ku materiálu $0,1-0,2(0,2-0,3) \mathrm{cm}$, laterální okraj spodní části $0,25-0,3(0,2-0,3) \mathrm{cm}$ a svrchní $0,3-0,45(0,275-0,35) \mathrm{cm}$. Je třeba brát v úvahu korozní činitele, ovšem z hlediska síly materiálu jsou exempláře z Kozla i Ronovce takřka identické (Knápek-Macků 2016, 168).

Druhá - horní - část je tvaru nepravidelného šestiúhelníku o rozměrech $4,7(5,1) \mathrm{cm}$ na výšku a 2,8 (2,9) cm na šiřku. Do středu tohoto dílu je proražen otvor ve tvaru křriže. Spodní část

2 Prvotní průzkum provedla PhDr. Alena Nachtmannová, Ph.D., v únoru 2019, děkujeme jí zde za její pomoc a poskytnuté informace (viz SOA Praha).

3 Nánosník byl rozpoznán na základě upozornění od kastelána Bc. Jana Polívky, kterému tímto děkujeme.

4 Metrické rozměry jsou udávány pro kozelský nánosník, v závorce pak údaje naměřené na ronoveckém exempláři. 
tvoří stočená tyčinka, která je nasazena mezi „očka“ spodního dílu, a pomocí kulatinky roznýtované na obou stranách je vytvořen otočný pant. Horní okraj je tvarován horizontálně se vzhůru vytaženým zahroceným výběžkem při levém okraji. Tento prvek se vyskytl i u ronoveckého nánosníku, kde jsme mu nevěnovali větší pozornost, nebot' jsme ho považovali, kvůli poškození této části, za zbytek destruované blíže neurčitelné hmoty. Nyní však lze s jistotou tvrdit, že jde, vedle rozpěrky ve tvaru kříže, o záměrnou opěrnou plochu sloužící k opření o výstupek na přilbě. Toto řešení zamezovalo pohybu nasazeného nánosníku (viz dále). Síla materiálu tohoto dílu je $0,4(0,5-0,6) \mathrm{cm}$ na všech stranách.

Pant sestávající ze tř́i částí je 1,8 (1,9) cm široký a 0,9 (1) cm vysoký. Je naprosto funkční a lze jím otáčet v plném rozsahu. Styčné plochy obou hlavních dílů jsou „ochozené“ a je možné, že pant byl opětovně rozpohybován teprve v průběhu nedávné doby. Funguje na principu rozepření zkosených hran horní a spodní části nánosníku, které se o sebe ve své nepravidelnosti rozpírají jak při sklopení, tak při odklopení (tj. pant je možné zafixovat v obou mezních pozicích). Váha kozelského exempláře je 84 gramů.

\section{Problematika vývoje nánosníků a základní typologie jejich zámků}

Rozbor vývoje nánosníků ve 14. století byl popsán dříve, a proto zde bude shrnut jen obrysově (Knápek-Macků 2016, 173-176, obr. 5-7). Potřeba chránit si obličej v bitvě nebyla žádnou novinkou. V raném středověku, a to až do 13. století byla oblíbená kónická, jedno- či vícekusová přilba s napevno uchyceným nánosníkem. Její mnohočetné vyobrazení nalezneme vedle iluminovaných rukopisů i na tapiserii z Bayeux (1066-1082; Blair 1959, 21, 25-27, obr. 2). Publikované exempláře známe např́íklad z Polska. Prvním je nález z Lednického jezera v Poznaňském vojvodství, kde je tato přilba datovaná do 11.-12. století s možným přesahem až ke konci století desátého. Druhá přilba pochází taktéž z jezera, tentokrát Orchowského ve Velkopolsku a datována je do 11.-12. století (Nadolski 1994). Z Rakouska známe exempláŕ z Hainburgu (Anonym 1914, 47, obr. 7; bližší informace podal M. Bernart 2010, uvádí ostatně i soupis všech přileb z našeho území). Ze Slovenska dále známe přilbu vyzvednutou při amatérském výkopu ve středu hradiska Bojná I. S ní byly vyzvednuty i fragmenty kroužkového závěsu z bronzových a železných kroužků, ovšem nález zůstal v soukromé sbírce. Typologicky i datačně (konec 9. - počátek 10. století) je tento nález blízký nálezu dvou přileb z Prahy - Stromovky (viz níže). Bližší informace prozatím nejsou publikovány (Pieta 2015, 27, 30, 33, obr. 17; Pieta-Robak 2017, 343).

U nás je jistě nejznámějším zástupcem tzv. přilba svatého Václava, která tvoří součást korunovačního pokladu v chrámu sv. Víta v Praze (Metropolitní kapitula v Praze, inv. č. K 168; Hejdová 1964; Laking 1920, 47, fig. 55). Vedle ní z našeho prostředí ovšem známe více kusů archaický exemplář z Hradska u Mělníka (9. století, Národní muzeum Praha; Turek 1963, 64); dvě přilby z Královské obory (Stromovky) v Praze (9.-12. století; Hejdová 1964), z Olomouce proboštství (Kunsthistorisches Museum Hofburg, 11.-12. století; Laking 1920, 45, fig. 57; Měřínský 2009, 219-227), další z Olomouce, tentokrát bez bližších nálezových okolností a dnes ztracená, další přilba, s nyní neznámou deponií, pocházela z jižní Moravy (sbírky hraběte Wilczka, 11.-12. století; Laking 1920, 45, fig. 56 a 58).

Tyto kónické přilby mizí v průběhu 13. století a kolem jeho poloviny jde už o archaický typ. Nahradily je zcela uzavřené helmy, tj. kaloty, a z nich později vyvinuté hrncové tvary, vedle kterých se udržovaly plechové klobouky. Vznikly i lehčí, vrch hlavy kryjící přilby typu cassis a bacinet (šlap). K posledním dvěma jmenovaným se pak opět začal nánosník přidávat, tentokrát však již volný, snímatelný. Od 30. let 14. století se tedy opět setkáváme s nánosníkem, ovšem zcela jiné konstrukce. Šlo o železné pletivo ve tvaru trojúhelníku, uchycené na kroužkový závěs přilby v místě brady. Mimo boj byl svěšen dolů a do bitvy si ho ozbrojenec připnul na výkovek uprostřed přilby v oblasti čela a př́ípadně zajistil zámkem (Knápek-Macků 2016, 172, obr. 5). Jeho ochrana však nebyla dostatečná, a proto byl ještě před polovinou 14. století nahrazen variantou plechovou, jehož morfologie i uchycení odpovídalo starší variantě (obr. 4:A-C). Kozelský a ronovecký 
nánosník jsou tedy technologicky nejvyspělejší variantou, která se přitom vyskytovala souběžně se starší plechovou variantou už nejspíše kolem či po polovině 14. století. Hlavním rozdílem vyspělejší varianty oproti té starší je princip odklápění nánosníku přes pant směrem nahoru, a tedy i jeho neuchycení ke kroužkovému závěsu přilby u brady (obr. 4:D-I). Systém zvedání a zajištění odpovídal jakémukoliv jinému hledí typu klappvisor (hledí, at' už snímatelné, nebo napevno uchycené uprostřed přilby v místě čela). V obou pozicích, jak zvednuté, tak sklopené, pak hledí zůstalo zafixováno díky důmyslnému zesilování a zužování kontaktních ploch všech jeho částí.

Tento typ nánosníku je četně vyobrazen např́iklad v rukopise Le livre et la vraye hystoire du bon roy Alixandre, nacházejícím se v The British Library (Royal MS 20 B XX). Konkrétně jde o osmnáct foliantů, na kterých je zachyceno celkem dvacet šest nánosníků, z nichž je patnáct sklopeno dolů a jedenáct odklopeno nahoru (fol. 16v, 33r, 44v, 49v, 50r, 51r, 51v, 54r, $55 \mathrm{v}, 60 \mathrm{r}, 63 \mathrm{r}, 64 \mathrm{r}, 65 \mathrm{r}, 68 \mathrm{v}, 75 \mathrm{v}, 78 \mathrm{v}, 79 \mathrm{r}, 94 \mathrm{v})$. Morfologicky jde o shora se zužující zahrocené tvary, jejichž spodní konec je vzhůru ohnut do tvaru háku, př́padně mírně esovitě prohnutý. Odklopené nánosníky mají tvar podobný dubovému listu (obr. 4:F-G). Nejčastěji jsou osazeny na vyspělé tvary bacinetů bez kroužkového závěsu, kdy je krk chráněn jen kroužkovým límcem či oboječkem v kombinaci s plechovým podbradím i bez něj (obr. 4:D-I). Jedenkrát je osazen nánosník na železném klobouku v kombinaci s bacinetem a železným podbradím (obr. 4:H). Tento typ kombinovaných přileb se sporadicky vyskytuje i v jiných pramenech, ale pro jeho další vyhodnocení nemáme zatím dostatek informací (ze starší literatury nap̌r. Funcken-Funcken 2001, 38-39). Nánosník je vyobrazen i na samotném klobouku (obr. 4:G) či cassis („lebce“; obr. 4:I). Byt' musíme být opatrní ohledně interpretace a stylizace iluminátora, zdá se, že nánosníky nemusely být osazovány jen na bacinety, jak jsme dosud soudili. Iluminace ovšem ukazují a potvrzují předchozí tvrzení, že nánosníky nosili jak prostí vojáci, tak i vrcholová šlechta (Knápek-Macků 2016, 177).

Nejjednodušším způsobem, jak zajistit uchycení hledí či nánosníku, bylo fixní uchycení na přilbu. Takové řešení, byt' už bez původního krytu obličeje máme dochováno na přilbě z Boves, dnes z Armeria Reale Torino, z třetí třetiny 14. století (Angeluci 1890), či na obraze Zmrtvýchvstáni Krista v Národní galerii v Praze, inv. č. 0 477, od Mistra Třeboňského oltáře z 80. let 14. století (Karel IV. 2006, 466-467). Nositel, který chtěl hledí střídat, pak mohl použít výkovek ve tvaru vzhůru obráceného háčku na přilbě. Zde však hrozilo jeho vypadnutí při prudkém pohybu, a proto mohl být navíc zajištěn kyvadlovou tyčinkou umístěnou nad háčkem $\mathrm{s}$ volnějším přinýtováním $\mathrm{k}$ přilbě. Pohybovala se do stran a po zavěšení nánosníku do háčku byla tyčinka otočena svisle dolů, kdy její spodní část tlačila na horní okraj hledí. Taková přilba, včetně kroužkového závěsu i nánosníku se dochovala v Armeria della Rocca (Mauro 1989, 20) v Higgins Armoury Worcesterského muzea umění, inv. č. 2014.842.1 (online WAM), v Metropolitan Museum v New Yorku, inv. č. 04.3.238 (MET), nebo ji lze vidět na náhrobku Günthera XXI. von Schwarzburg v katedrále sv. Bartoloměje ve Frankfurtu nad Mohanem, který je datován post quem 1349 (Knápek-Macků 2016, 174, obr. 6:F). Nejjistější řešení dokládá zámek přilby uložené v Kunstsammlungen der Veste Coburg, inv. č. A. I. 1, z počátku 15. století (Scalini 1996, 57), přilby v Deutsches Historisches Museum, inv. č. W 975, 99.32, z doby okolo roku 1370 (online DHM), náhrobky Ulricha V. Landschada von Steinach v německém Neckarstainachu († 1369) či Galeotta Malaspiny v italském Fosdinovu († 1367; Laking 1920, 228-230; E \& B). Jde opět o tyčinku kyvadlového charakteru, která však ve svislé poloze svou spodní částí nasazený nánosník nerozpírá, nýbrž celý zakryje svrchu. Z hlediska větší jistoty proti sklouznutí bývala spodní část zámku někdy rozšířená do tvaru kladiva. Tato varianta se nám jeví jako nejpravděpodobnější k zafixování kozelského nánosníku. Po usazení nánosníku na výkovek ve tvaru kříže se jeho horní část navíc zapřela o druhý výkovek umístěný nad ním a poté zafixovala „kyvadlovým“ zámkem. Zámků existovalo mnoho variant a modifikací, typických pro experimenty 14. století v rozvíjejícím se helméřském a platnéřském řemesle. Není však cílem zde popisovat všechny, uvedli jsme tedy jen ty nejrozšířenější. 


\section{Historický rámec}

Vzhledem k prvotnímu předpokladu, že nánosník pochází z hradu Lopata, jsme ho zkusili přiložit k přilbě typu bacinet uložené v Západočeském muzeu v Plzni, inv. č. HA 3841, podle literatury nalezené tamtéž (Frýda 1996, 534; Novobilský 2008, 87, obr. 96; Žákovský 2011, 873, obr. 320, k názvosloví přileb Wagner-Durdík-Drobná 1956, 59-64; nejnověji Knápek-Macků 2016, 169173; původ nálezu je však nejistý). ${ }^{5}$ Stejně tak jsme zkusmo přiložili k přilbě nánosník z Ronovce. ${ }^{6}$ Na přilbě se nedochoval výkovek, který byl nanýtován v místě uprostřed čela a na který se nánosník narazil. Podle analogií a sepulkrálních památek v podobě tehdejších šlechtických náhrobků však víme, že k nejčastějším patřily obdélníky s háčkem, kříže či jejich varianty a kombinace. Výkovek je sice ztracen, ale zůstala po něm obdélný otvor skrz hmotu přilby, jímž byla její spodní část prostrčena a roznýtována. Její tvar pak zaručoval pevné uchycení a nemožnost pootočení.
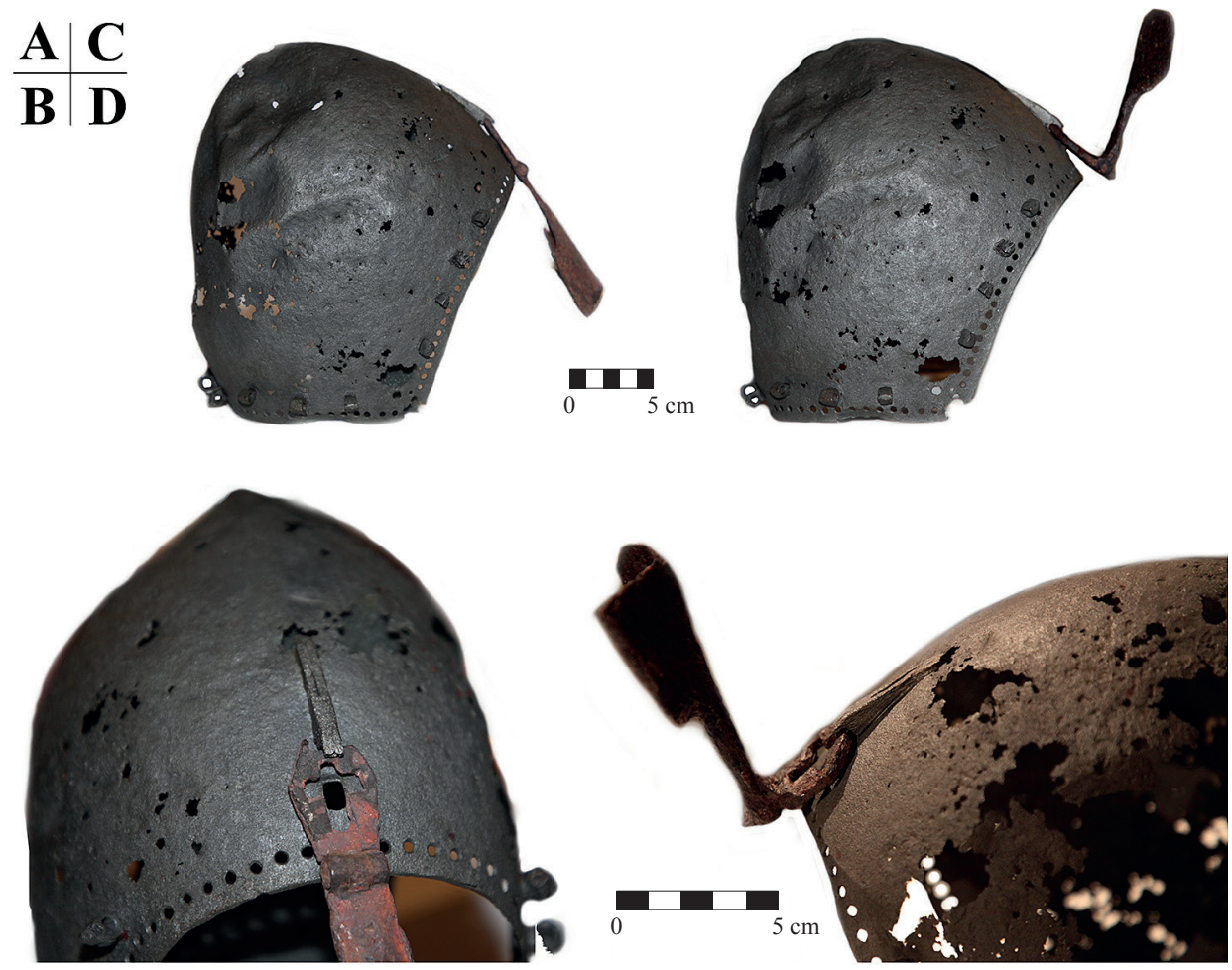

Obr. 3. Orientační přiložení nánosníku z kozelských sbírek (A-B) a z hradu Ronovce (C-D) k nekompatibilní přilbě z hradu Lopata (?). Foto a úprava P. Macků, 2019.

Abb. 3. Grobes Aufsetzen des Nasals aus den Kozeler Sammlungen (A-B) und des von Burg Ronovec (C-D) mit dem nicht kompatiblen Helm von Burg Lopata (?). Foto und Bearbeitung P. Macků, 2019.

5 Dle sdělení Mgr. Jiřího Orny (2019) ze Západočeského muzea v Plzni, kterému tímto děkujeme za zpř́istupnění předmětu v muzejní expozici a konzultaci, však přilba z hradu Lopata nepochází a za dané situace nelze přesněji určit její původ.

6 Za jeho zapůjčení pro potřeby srovnání a otestování na přilbě děkujeme panu Jiřímu Polívkovi z Muzea obce Dolní Krupá. 
Dochována však zůstala horní svislá tyčinka, zespodu nanýtovaná k přilbě pomocí jednoho nýtu s kulatou hlavičkou usazenou na kruhové podložce. Je tvarovaná tak, že od své základny, kde je zároveň schůdek pro založení zámku hledí, se od základny směrem nahoru její hmota snižuje. Otázkou zůstává, zda byla tato opěrka hledí přinýtována napevno, nebo byla otočná do stran. Pak by její funkcí bylo po naražení hledí na čep otočením do svislé polohy toto hledí fixovat. Tuto pohyblivou variantu ukazuje např́íklad socha v Dóžecím paláci v Benátkách z poloviny 14. století, náhrobky výše citovaného Ulricha V. von Landschada, Johanna von Falkenstein či Galeotta Malaspiny (oba z 60. let 14. století; E \& B). Na dochovaných exempláŕích pak lze tento systém dokumentovat na přilbě uložené ve Walliser Kantonsmuseen / Geschichtsmuseum Wallis, Sitten, inv. č. MV30. Vzhledem ke stavu přilby ze sbírek Západočeského muzea však nelze ani jednu tezi o fixaci hledí potvrdit či vyvrátit.

Nánosník na přilbu sedí (obr. 3:A-B), nicméně jeho horní část s výše popsaným zahroceným vrchlíkem, sloužícím k zapření o horní zarážku, nekoresponduje. Oba kusy tedy k sobě nejspíše nepatří. Celkově nánosník od přilby výrazně odstává, což znázorňují i některé dobové iluminace (srov. obr. 3:A a obr. 4:E, H).

Otázku, zda si nánosníky vyráběli sami platnéři, od nich oddělení helméři či jiní kováři, nelze přesně zodpovědět. Byt’ šlo v principu o jednoduchou záležitost, musely být oba nánosníky vyrobeny zkušeným řemeslníkem, především kvůli pantu a přesnosti sbroušení jeho hran (rozpěrek).

Platnéŕi (thorifices) byli s rozvojem svého řemesla od konce 13. století na vzestupu, což dokládají zmínky od roku 1328, kdy se v Praze začali sdružovat. Nejstarší jménem známý je platnéř Klebel, zmíněný v roce 1329, a do roku 1393 se jen na Starém Městě přihlásilo dalších 24 mistrů. Pocházeli z italského Coma (1354), z Týnce, Kolína, Berouna a Chrudimi či Norimberka. Roku 1351 se objevuje platnéř Rudl i přímo mezi konšely. K roku 1427 staroměstské berní rejstříky uvádějí osm platnéřů. I ve válečných letech byl jeden z konšelů platnéř, totiž Vůz (1423). Další přímo jmenovaní jsou Lekeš (1424), Makovec (1429), Štěpán (1429), Ocásek (1435), všichni opět ze Starého Města. Do roku 1526, tedy z doby vrcholného platnéřského řemesla, je známo v Praze 26 mistrů, přičemž mezi konšely byli dva na Starém Městě. Jménem známe Stomila (1477), Heinrica Hemerleho žijícího v Ostrožnické ulici (1439), dále jsou to Křŕž thorifex (kolem $1450, \dagger 1463)$, Janek Legát (1454), Vocásek (1463 - syn výše jmenovaného Ocáska?), Smetana (1464), Škoda (1472), Duchek Popel (1473) a Šimon, thorifex řečený Albus Leo, Havel Kabele nebo Cabela (1477), který s Duchkem společně podnikal, Pivce Václav (1479), Jan Důbek, Sladký (1483), další Pivce, Jan (1516), Jan Biberka (1486) a v neposlední řadě platnéřka Křížová (1454). Jeden z nich byl původem $\mathrm{z}$ Vlašimi, ale i $\mathrm{v}$ dalších městech známe tyto řemeslníky: $\mathrm{v}$ Táboře byl jeden (1432), koncem patnáctého století byl v Berouně a roku 1483 dlužil v Praze platnéř z Jindřichova Hradce (Winter 1906, 150, 237-238, 240, 397-398, 401-402, 463).

Z. Winter $(1906,80)$ taktéž píše, že helméři (galeatores, přielbičnik, helmsmit, helmer) byli u nás ve třináctém století spíše vzácnější, potažmo se začali teprve od platnéřủ vyčleňovat. Nejstarší zmínka pochází z prostředí dvora Přemysla Otakara II. a Václava II., kdy je zmiňován helméř Gunther z Lokte. Po něm je znám z václavovského prostředí Jindřich z Vídně. Ve 14. století jsou doloženi v Praze dva (jeden původem z Řezna, 1343), do roku 1419 tři, k roku 1422 přímo jmenován Jakub. O jejich regulaci však svědčí řád staroměstské rady z roku 1328, která zde zakazovala pracovat bez měštanského stavu platnéřům, štítařům a helméřům. Ze závěru středověku je znám konšel Martin z Malé Strany k roku 1495 (Winter 1906, 151, 190, 463). Z roku 1385 máme unikátní záznam o výbavě helméře Kunce, který kvůli dluhům dal do zástavy kovadlinu, měchy, kleště a kladiva „rohatiny“ v celkové částce 3 kopy a 27 grošů (Wágner-Durdík-Drobná 1956, 25-26).

Kroužkové závěsy k přilbám, stejně jako kroužkové varianty nánosníků si mohli helméři objednávat u zbrojír̆u - fabri armorum, které v našem prostř̌edí zmiňuje už Kosmas, či brnírư (lorifices, loricator, panceriator, panczirer, sarbuch). Brníře známe z Prahy jediného, totiž Peška z Boleslavi zmíněného k roku 1354. Další je uveden pak až k roku 1420 v Plzni a také z Hradce Králové. Z období husitských válek, přesněji k roku 1427, víme o třech, k roku 1429 o jednom 
na Starém Městě pražském, který se jmenoval Mařík. Jejich spojený cech s dalšími řemesly je znám z Jihlavy k roku 1349, ze zdroje se však nedozvíme nic více než výši plateb při přijímání nových adeptů. Další cech brnírů je znám ze Starého Města pražského k roku 1454. U jejich tovaryšů máme dochovaný zápis k finančnímu ohodnocení: ti, co vyráběli oboječky, dostávali týdně 7 grošů, nejlepší „naigléř“, který vytvářel pruhy pletiva, 6,5 grošů, ten, co dělal lehčí kusy, 5 grošůn, výrobce drátu pak 4,5 grošů (Wagner-Durdík-Drobná 1956, 26; Winter 1096, 9, 80, $150-151,200,237,258-259,397-399,401,577,738,827)$.
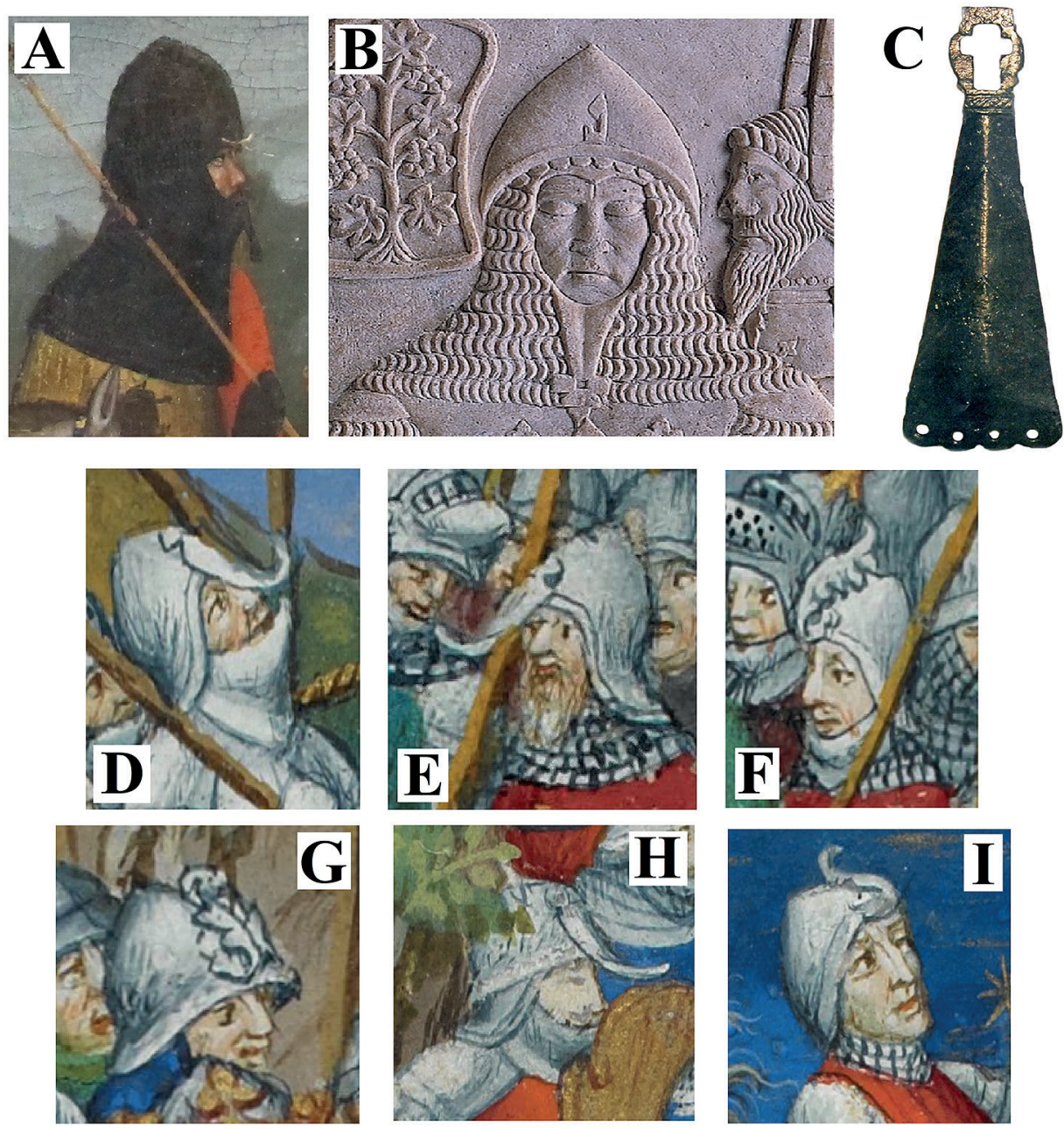

Obr. 4. Nejrozšířenější varianta s ukázkou méně známého originálu $(A-C)$ a vzhůru odklopné nánosníky (D-I). A - Scéna z Ukřižování Krista (výřez), následovník Giotta, Louvre, inv. č. MI 358 (POP); B - náhrobek Giacotta Provana, Carignana, (zaniklý) kostel Santa Chiara, Itálie, 1382 (MRT); C - Amersfoort, Nizozemí, okolo 1375 (Brokamp 2005, 2); D-I - Le livre et la vraye hystoire du bon roy Alixandre, fol. 65r, 54r, 60r, 68v, 49v, 64r (Royal MS 20 B XX). Úprava P. Macků.

Abb. 4. Verbreiteste Variante mit Beispielen des weniger bekannten Originals (A-C) und mit hochgeklapptem Nasal (D-I). A - Szene aus Die Kreuzigung Christi (Ausschnitt), Nachahmer von Giotto, Louvre, Inv.-Nr. MI 358 (POP); B - Grabmal von Giacotto Provana, Carignano, (untergegangene) Kirche Santa Chiara, Italien, 1382 (MRT); C - Amersfoort, Niederlande, um 1375 (Brokamp 2005, 2); D-I - Le livre et la vraye hystoire du bon roy Alixandre, fol. 65r, 54r, 60r, 68v, 49v, 64r (Royal MS 20 B XX). Bearbeitung P. Macků. 
Dobovou cenu nánosníků asi nezjistíme, můžeme jen odhadovat podle cen přilbic: v roce 1440 stála „lebka“ čistá (asi leštěná?) 24 grošů, plechový klobouk 40 grošů a v roce 1470 kopu a půl grošů. Brnír Oldřich Hemrle prodal v Praze sedm pancíŕů, přilby s hledím a šorcy za 25 kop grošů (Wagner-Durdík-Drobná 1956, 26). Brnír Mařík v Praze roku 1433 prodal „ocelivý pancíř“ za 6 kop pražských, v polovině století jiný brnír Šimon prodával stejnou komoditu za 4-5 kop. Vyskytly se však varianty levnější - za 3 zlaté uherské, ale i luxusní za 13 kop grošů. „Čisté pláty“ prodával v Praze platnéř Kříž roku 1440 za 70 grošů, prusplech černý (hrudní plát) za 15 grošů, dvoje myšky a nákolenky za kopu, rukavice za 26 grošů a turnajová zbroj s helmou stála pět kop grošů. V roce 1486 byla v Praze prodána „posáklá a dobře chatrná zbroj“ za 5 uherských dukátů. Písemně máme i doloženo zlacení zbrojí (Winter 1906, 817, 827-828).

Uvedené písemné prameny nám samozřejmě poskytují pouze vhled do prostředí vrcholného a pozdního středověku, přičemž zde jsme vypsali především stav měšt’anský z pražského Starého Města, kde jsou předmětné prameny nejčetnější. Zdokumentované jsou však i Nové Město pražské, Brno, Jihlava, Znojmo, Louny, Chrudim, Kolín, Tábor a další. Připočteme-li i další obyvatele měst, pak se počty ještě navýší (problematiku jejich četnosti řešili podrobně Wagner-Durdík-Drobná 1956, 27-44). Prameny nicméně naznačují, že zbrojní řemesla se u nás flexibilně rozvíjela, specializovala a během 14 . století nastal jejich rychlý vzestup i díky přesunu řemeslníků z jiných zemí k nám (Itálie, Německo, Polsko), čehož důsledkem byly nové pracovní a technologické impulzy.

Otázkou zůstává provenience předmětných nánosníků. Ve 14. století byla sít' specializovaných řemeslníků poměrně hustá a pokrývala poptávku, zároveň víme, že se k nám militaria nejen dovážela, ale i vyvážela. Zbrojní řemesla byla od 14. století zastoupena vedle Prahy i v ostatních městech královských, ale vyskytovala se, byt' v menším zastoupení i městech poddanských (Wagner-Durdík-Drobná 1956, 26, 44). Ačkoli jde v prŕípadě nánosníků o předměty morfologicky ustálené, musely být vyráběny přímo pro daný tvar přilby, úchytek či zámků, jak ukázal i náš pokus o nasazení pojednávaných nánosníků na přilbu ze sbírek Západočeského muzea.

\section{Diskuse}

Máme-li pro ronovecký nález velmi málo informací, pak pro kozelský nejsou prakticky žádné. Ronovecký nánosník je na základě písemných pramenů datován do třetí čtvrtiny 14. století a u kozelského exempláře jistě nepochybíme, když ho zařadíme stejně. Podle četnosti vyobrazených nánosníků v manuskriptu Alexandreidy z let 1420-1425 lze uvažovat i o jejich běžném výskytu v době počátku husitských válek (Royal MS 20 B XX).

Díky takřka stejné morfologii obou kusů, technologii výroby i použitým materiálům lze totiž uvažovat přímo o stejné výrobní dílně. Šlo by tak o přímý důkaz sériové výroby, která se začala šírit od 13. století s řemeslnou specializací především ve městech.

\section{Prameny}

ANM 1: Archiv Národního muzea, fond Archeologický sbor - č. 170, karton č. 1. 13, b.

ANM 2: Archiv Národního muzea, fond Registratura Národního muzea, karton č. 4, složka D1-5.

ANM 3: Archiv Národního muzea, fond Registratura Národního muzea, karton 14, složka P2 - 1822, $1,3$.

SOA PRAHA: Různá, blíže neurčená korespondence, inv. č. 3372, 3373, kart. 33, a inv. č. 3374, 3375, kart. 34.

- Korespondence se sekretářem J. Goppoldem a vrchním Svobodou 1816-1848, inv. č. 3770, kart. 92.

- Různé k činnosti Vincence z V. a Kristiána z V. 1744-1845, inv. č. 2893, kart. 109.

- Dopisy Kristiána různým osobám 1838-1859, inv. č. 4002, kart. 134.

- Dopis od Vocela se nachází v inv. č. 3375, kart. 34, 108. 254 sl. 


\section{Literatura}

ANGELUCCI, A., 1890: Catalogo della Armeria Reale. Torino.

ANONYM, 1914: Mittelalterliche Helme aus dem Besitze Sr. Exz. Des Grafen Hans Wilczek. Sammlung Schlofs Kreuzenstein. In: Zeitschrift für historische Waffenkunde. Band 6, Heft 2, 41-47. Leipzig.

BERNART, M., 2010: Raně středověké př́ilby, zbroje a štíty z Českých zemí - Early medieval helmets, armour and shields from Czech lands. Diplomová práce, Univerzita Karlova v Praze, Filozofická fakulta, Ústav pro pravěk a ranou dobu dějinnou, vedoucí práce Prof. PhDr. Jiří Sláma, CSc.

BROKAMP, B., 2005: Een raadsel opgelost; vondst blijkt onderdeel wapenuitrusting. In: Oudheidkundige Vereniging Flehite, Kroniek: Tijdschrift Historisch Amersfoort. Jaargang 7, č. 4, 2-3. Amersfoort: Museum Flehite.

BLAIR, C., 1959: European Armour. Circa 1066 to circa 1700. New York.

FRANC, F. X., 1988: Štáhlauer Ausgrabungen 1890. Díl 1. Přehled nalezišt’ v oblasti Mže, Radbuzy, Úhlavy a Klabavy 1906 (Šaldová, Věra, ed.). Praha.

FUNCKEN, L.-FUNCKEN, F., 2001: Historische Waffen und Rüstungen. Ritter und Landsknechte vom 8. bis 16. Jahrhundert. Mittelalter und Renaissance. Niedernhausen.

BEČKOVÁ, J., 2008: Valdštejnové a Třebíč 1613-1945. Třebíč.

FRÝDA, M., 1996: Militaria. In: Gotika v západních Čechách (1230-1530) II. (Fajt, J., ed.), 531-535. Praha. HEJDOVÁ, D., 1964: Přilba zvaná „Svatováclavská“, SbNM A XVIII, 1-106.

KAREL IV., 2006: Karel IV. Císař z Boží milosti. Kultura a umění za vlády Lucemburků 1310-1437 (Fajt, J., ed.). Praha.

KNÁPEK, A.-MACKU゚, P., 2016: Unikátní součást zbroje z hradu Ronovce (okres Havlíčkův Brod) - Ein einzigartiger Bestandteil einer Rüstung von Burg Ronovec (Bezirk Havlíčkův Brod), AH 41 167-180.

LAKING, G. F., 1920: A record of armour and arms through seven centuries. Vol. I. London.

MAURO, M., 1989: Armeria della Rocca. Mostra di armi antiche. Mondavio.

MĚŘÍNSKÝ, Z., 2009: Morava součástí přemyslovského státu. In: Přemyslovci. Budování českého státu (Sommer, P.-Třeštík, D.-Žemlička, J., edd.), 219-227. Praha.

NADOLSKI, A., 1994: Polska technika wojskova do 1500 roku. Z dziejów nauki i techniki 1. Warszawa. NOVOBILSKÝ, M., 2008: Obléhání hradu Lopaty. Rekonstrukce obléhání hradu z roku 1432-1433. Plzeň.

NOVOSADOVÁ, O., 1977: Státní zámek Kozel u Št’áhlav, dějiny objektu. Zpráva č. PPOP037-4*14531, ulož. ve Státním ústavu pro rekonstrukce památkových měst a objektů v Praze.

PIETA, K., 2015: Včasnostredoveké mocenské centrum Bojná - výskumy v rokoch 2007-2013. In: Bojná 2. Nové výsledky výskumov včasnostredovekých hradísk (Pieta, K.-Robak, Z., edd.), 9-49. Nitra.

PIETA, K.-ROBAK, Z., 2017: The early medieval hillfort Bojná - Valy, Slovakia, and its defence systém, Acta archaeologica Carpathica LII, 329-351.

SCALINI, M., 1996: The Armory of the Castle of Chruburg. Udine.

ŠOLLE, M., 1998: Hradsko na Kokořínsku - Camburg franckých análů. Praha.

ŠTUMBAUER, T., 2014: Výzkum rodokmenu Valdštejnů z mobiliárního fondu zámku Kozel, ZPP LXXIV, 474-481.

TUREK, R., 1963: Čechy na úsvitě dějin. Praha.

WAGNER, E.-DURDÍK, J.-DROBNÁ, Z., 1956: Kroj, zbroj a zbraně doby předhusitské a husitské. Praha.

WINTER, Z., 1906: Dějiny řemesel a obchodu v Čechách. Praha.

ŽÁKOVSKÝ, P., 2011: Zbraně a zbroj z první poloviny 14. století ve střední Evropě. Katalog militarií. In: Král, který létal. Moravsko-slezské pomezí v kontextu středoevropského prostoru doby Jana Lucemburského (Majer, D., ed.), 841-879. Ostrava.

\section{Internetové zdroje}

DHM - Deutsches Historisches Museum, Berlin. Dostupné z: https://www.dhm.de/archiv/ausstellungen/eisenkleider/frueh/kat032.htm, cit. 10. 3. 2020. 
E\&B - Effigies \& Brasses: Database \& Image Collection. Dostupné z: http://effigiesandbrasses.com/, cit. 10. 3. 2020.

MET - Metropolitan Museum of Art, New York. Dostupné z: http://www.metmuseum.org/collection/the-collection-online/search/25393?rpp=30\&pg=1\&ft=04.3.238\&pos=1, cit. 10. 3. 2020.

MRT - Musei Reali Torino. Dostupné z: https://www.museireali.beniculturali.it/catalogo-on-line/\#/dettaglio/53263_Lastra\%20tombale\%20di\%20Giacotto\%20Provana, cit. 9. 3. 2020.

POP - Plateforme Ouverte du Patrimoine, Ministère de la Culture France. Dostupné z: https://www.pop. culture.gouv.fr/notice/joconde/000PE027387, cit. 9. 3. 2020.

Royal MS 20 B XX, Le livre et la vraye hystoire du bon roy Alixandre, The British Library (Royal MS 20 B XX). Dostupné z: http://www.bl.uk/manuscripts/FullDisplay.aspx?ref=Royal_MS_20_B_XX\&in$\operatorname{dex}=16$, cit. 10. 3. 2020 .

WAM - Worcester Art Museum, Higgins Armoury. Dostupné z: https://worcester.emuseum.com/objects/50434/basinet-helm-with-aventail-mail-hood-and-dogfaced-visor?ctx=9a819c30-8c10-4e2a-8d05-9ed1c4467aec\&idx=0, cit. 10. 3. 2020.

\section{Zusammenfassung}

Ein hochmittelalterliches Nasal aus dem Mobiliarbestand des staatlichen Schlosses Kozel als Beispiel für die ersten archäologischen Grabungen und Möglichkeiten seiner Interpretation

Im 19. Jahrhundert hat sich zusammen mit dem Interesse an der Wissenschaft unter einigen gebildeten Angehörigen des Adels auch die Vorliebe für historische Untersuchungen von Denkmälern in der Umgebung ihrer Adelssitze verbreitet. Mit den Untersuchungen gelangten verschiedene Gegenstände in die Schlossbibliotheken und -kabinette, die von solchen amateurhaften Untersuchungen stammten. Im Mobiliarbestand von Schloss Kozel (Waldschloss, Bezirk Pilsen-Stadt) ist uns dank dieser Vorliebe ein Konvolut archäologischer Funde überliefert, die aus zwei Perioden der ersten in der Umgebung von Štáhlavy (Stiahlau, Bezirk Pilsen-Stadt) durchgeführten archäologischen Ausgrabungen stammen. Ein markantes Denkmal unter diesen Gegenständen ist ein unter der Inventarnummer KZ3481 erfasstes, unikat erhaltenes Nasal (Abb. 1 links).

Das Artefakt ist fast identisch mit einem kürzlich publizierten Nasal von Burg Ronovec (Knápek-Macků 2016). Es handelt sich um Gegenstände mit gleicher Morphologie und denselben Abmessungen, und dank der besseren Erhaltung des Kozeler Nasals können durch ihn einige früher skizzierte Schlussfolgerungen präzisiert werden (vgl. Abb. 1-2).

Im Hinblick auf die primäre Annahme, dass das Nasal von Burg Lopata stammt, haben wir versucht, es an eine im Westböhmischen Museum in Pilsen aufbewahrte Beckenhaube anzulegen (Inv.-Nr. HA 3841), die laut Literatur auch an derselben Stelle entdeckt wurde (nach Frýda 1996, 534; Novobilský 2008, 87, Abb. 96; Žákovský 2011, 873, Abb. 320). Ebenso haben wir versuchsweise das Nasal von Burg Ronovec an die Beckenhaube angelegt. Das Nasal passt auf die Beckenhaube (Abb. 3:A-B), nichtsdestotrotz korrespondiert sein Oberteil nicht mit der spitz zulaufenden Helmglocke, die zur Verriegelung in der oberen Raste diente. Beide Stücke passen demnach nicht zueinander. Das Nasal steht dann insgesamt deutlich von der Beckenhaube ab, was auch in einigen zeitgenössischen Illuminationen anschaulich dargestellt wird (vgl. Abb. 3:A a Abb. 4:E, H).

Für diesen Nasaltyp finden sich zahlreiche Abbildungen in der sich in der British Library (Royal MS 20 B XX) aufbewahrten Handschrift Le livre et la vraye hystoire du bon roy Alixandre. Konkret geht es dabei um achtzehn Folianten, in denen insgesamt sechsundzwanzig Nasale abgebildet werden, von denen fünfzehn nach unten und elf nach oben geklappt sind (fol. 16v, 33r, $44 \mathrm{v}, 49 \mathrm{v}, 50 \mathrm{r}, 51 \mathrm{r}, 51 \mathrm{v}, 54 \mathrm{r}, 55 \mathrm{v}, 60 \mathrm{r}, 63 \mathrm{r}, 64 \mathrm{r}, 65 \mathrm{r}, 68 \mathrm{v}, 75 \mathrm{v}, 78 \mathrm{v}, 79 \mathrm{r}, 94 \mathrm{v})$. Morphologisch handelt es sich um spitz zulaufende Formen, deren unteres Ende hakenförmig nach oben gebogen, ggf. leicht s-förmig zurechtgebogen ist. Die aufgeklappten Nasale haben die Form eines Eichenblattes (Abb. 4:F-G). Am häufigsten sind sie an ausgereiften Formen der Beckenhaube angebracht ohne 
aufgehängtes Ringelpanzergeflecht, durch das der Hals mit einem Ringelpanzerkragen oder -halsband kombiniert mit einem Kinnschutz aus Blech oder auch ohne einen solchen geschützt wird (Abb. 4:D-I). Einmal ist das Nasal an einem Eisenhut kombiniert mit einer Beckenhaube und einem Eisenkinnschutz angebracht (Abb. 4:H). Dieser kombinierte Helmtyp kommt sporadisch auch in anderen Quellen vor, jedoch verfügen wir für seine weitere Auswertung bislang über nicht genügend Informationen. Ein Nasal ist auch an einem Hut (Abb. 4:G) bzw. einem Cassis (französisch „Schädel“; Abb. 4:I) selbst angebracht. Selbst wenn wir hinsichtlich der Interpretation und Stilisierung des Illuminators vorsichtig sein müssen, scheint es, dass Nasale nicht allein an Beckenhauben angebracht worden sein mussten. Die Illuminationen zeigen allerdings und bestätigen die vorhergehende Behauptung, dass Nasale sowohl von einfachen Soldaten, als auch vom Hochadel getragen wurden (Knápek-Macků 2016, 177).

Wenn wir also über den Fund von Burg Ronovec nur sehr wenige Informationen haben, dann gibt es für den von Schloss Kozel praktisch gar keine. Das Nasal von Ronovec wird anhand der schriftlichen Quellen in das dritte Viertel des 14. Jahrhudnerts datiert, und beim Exemplar von Schloss Kozel gehen wir sicherlich nicht fehl, wenn wir ihn ebenso einordnen. Gemäß der Häufigkeit der in einer Handschrift der Alexandreis aus den Jahren 1420-1425 abgebildeten Nasale, kann man in Betracht ziehen, dass sie auch zur Zeit des Beginns der Hussitenkriege gängig waren (Royal MS 20 B XX).

Desgleichen bleibt die Frage nach der Provenienz beider Exemplare offen, und aufgrund ihrer gemeinsamen Ähnlichkeit kommt auch die Frage auf, ob sie nicht in derselben Werkstatt bzw. von demselben Handwerker hergestellt sein konnten. Demnach würde es sich hier um einen direkten Nachweis für eine Serienherstellung handeln, die sich ab dem 13. Jahrhundert mit der handwerklichen Spezialisierung in den Städten zu verbreiten begann.

Mgr. Pavel Macků, Národní památkový ústav, územní odborné pracoviššč v Telči, Hradecká 6, 58856 Telč, Česká republika,macku.pavel@npu.cz

Mgr. Veronika Pilná, Ph.D., Národní památkový ústav, územní odborné pracoviště v Plzni, Prešovská 7/171, 30637 Plzeň, Česká republika, pilna.veronika@npu.cz 

